\title{
Adenylate Cyclase and Guanylate Cyclase in Myxococcus xanthus
}

\author{
By A. L. DEVI AND H. D. MCCURDY* \\ Department of Biology, University of Windsor, Windsor, Ontario, Canada N9B $3 P 4$
}

(Received 20 July 1983; revised 4 January 1984)

\begin{abstract}
Myxococcus xanthus M300 vegetative cells contained significant amounts of adenylate and guanylate cyclase activity. The latter was distributed between the $100000 \mathrm{~g}$ supernatant and pellet fractions, required divalent cations for activity and exhibited an apparent $K_{\mathrm{m}}$ of $1 \mathrm{mM}$. Adenylate cyclase activity was detected both in the $100000 \mathrm{~g}$ supernatant and pellet. The supernatant enzyme had an apparent $K_{\mathrm{m}}$ of $220 \mu \mathrm{M}$ with a Hill coefficient of 1.9 , whereas the pellet enzyme had a $K_{\mathrm{m}}$ of $72 \mu \mathrm{M}$ and a Hill coefficient of $1 \cdot 0$. The isoenzymes differed in their $\mathrm{pH}$ optima and divalent cation requirements for optimal activity. During development of Myxococcus xanthus, the nucleotide cyclase activities exhibited changes that were substantially consistent with the roles postulated for each in a previously proposed model.
\end{abstract}

\section{INTRODUCTION}

Addition of cyclic nucleotide phosphodiesterase (PD) to developing Myxococcus xanthus increased territory size and accelerated aggregation; guanosine $3^{\prime}: 5^{\prime}$-monophosphate (cGMP) was antagonistic to the PD effect (McCurdy et al., 1978). Exogenous adenosine 3' $: 5^{\prime}$-monophosphate (cAMP), however, increased the number of fruiting bodies but did not influence the PD effect. These findings and results from other laboratories (Parish et al., 1976; Zusman, 1978; Yajko \& Zusman, 1978) led to the proposal that cAMP functions as a derepressor of development-specific genes and that cGMP is involved in aggregation chemotaxis (McCurdy et al., 1978).

Consistent with this hypothesis was the report that cAMP concentration peaked immediately after induction, that cGMP peaked intracellularly between 18 and $28 \mathrm{~h}$ and exhibited an extracellular peak corresponding to aggregation and that the PDs for both nucleotides were maximal at the times of aggregation (Ho \& McCurdy, 1980). Furthermore, under fruiting conditions cGMP was a chemoattractant for $M$. xanthus (Ho \& McCurdy, 1979). In this paper we report results of an examination of adenylate and guanylate cyclase and their behaviour during development.

\section{METHODS}

Organism and growth conditions. Methods of vegetative cultivation, fruiting body induction and cell harvest at various stages of development of Myxococcus xanthus M300 were as described previously (Ho \& McCurdy, 1980).

Enzyme preparation. Toluene treatment of cells was done according to Harwood \& Peterkofsky (1975): $10 \mu \mathrm{l}$ toluene was added to $1 \mathrm{ml}$ of cell suspension containing approximately $0.5 \mathrm{mg}$ protein $\mathrm{ml}^{-1}$, and incubated at $30{ }^{\circ} \mathrm{C}$ for $10 \mathrm{~min}$.

For preparation of crude homogenate and preliminary fractionation, cells were suspended in homogenizing buffer consisting of $50 \mathrm{~mm}$-Tris $/ \mathrm{HCl}, \mathrm{pH} 7.5 ; 10 \mathrm{~mm}-\mathrm{MnSO}_{4} ; 3 \mathrm{~mm}$-mercaptoethanol and $20 \%(\mathrm{v} / \mathrm{v})$ glycerol. The cells were broken by two bursts of sonication of $20 \mathrm{~s}$ duration with a Bronwill Biosonik (Bronwill Scientific, Rochester, NY, USA), set at full power. The cell extract obtained after low speed centrifugation ( $7000 \mathrm{~g})$ was centrifuged at $100000 \mathrm{~g}$ for $90 \mathrm{~min}$ at $4{ }^{\circ} \mathrm{C}$. The clear supernatant was removed and the pellet was resuspended in homogenizing buffer to a final volume equivalent to the original volume.

Enzyme assays. Adenylate cyclase was measured essentially by the method of Terasaki et al. (1978). The $100 \mu \mathrm{l}$

Abbreviation: PD, phosphodiesterase. 
reaction mixture contained $50 \mathrm{~mm}-\mathrm{Tris} / \mathrm{HCl}, \mathrm{pH} 7 \cdot 5 ; 2 \mathrm{~mm}-\mathrm{MnSO}_{4} ; 2$ mM-creatine kinase; 2 mM-phosphocreatine, $3 \mathrm{~mm}$-sodium azide; $0.05 \mathrm{~mm}$-ethanol and $2 \mathrm{mM}-1$-methyl-3-isobutylxanthine (a cyclic nucleotide phosphodiesterase inhibitor in $M$. xanthus, Ho \& McCurdy, 1980); 2 mM-mercaptoethanol and $0 \cdot 1$ mM-ATP. The reaction was incubated at $30^{\circ} \mathrm{C}$ for $10 \mathrm{~min}$ and then stopped by adding $85 \mu 10.2 \mathrm{M}$-acetic acid at $4^{\circ} \mathrm{C}$, followed by boiling for $3 \mathrm{~min}$. After cooling, $15 \mu \mathrm{l} 0.8 \mathrm{M}-\mathrm{NaOH}$ was added to neutralize the reaction mixture and cAMP determinations were made by using the radioimmune assay of Steiner et al. (1972). Data analysis was by the computer program of Brooker et al. (1979).

Guanylate cyclase was measured essentially by the method of Garbers \& Murad (1979), except that 1 mM-GTP was used as the substrate. Product was measured by the radioimmune assay of Steiner et al. (1972) and the data analysis program of Brooker et al. (1979). Tris/ $\mathrm{HCl}$, Tris/maleate, glycine/ $\mathrm{NaOH}$ and $\mathrm{HEPES}$ buffers were used for $\mathrm{pH}$ optimum determinations for both guanylate and adenylate cyclases.

The method of Lowry was used for protein determinations, with bovine serum albumin as the standard.

Biochemicals. The following compounds were obtained from Sigma: GTP (lithium salt), 1-methyl-3-isobutylxanthine, 2-mercaptoethanol, sodium azide, creatine kinase, phosphocreatine, Tris, HEPES, maleic acid and glycine. The radioimmunoassay (RIA) kits were obtained from New England Nuclear.

For liquid scintillation counting, the filmware plastic bags $(10 \mathrm{ml})$ were obtained from Nalge, Rochester, NY, USA. Triton X-100 was obtained from Rohm and Haas, West Hill, Ontario, Canada. 2,5-oxazole (PPO) and 1,4di-2-(5-phenyloxazolyl)benzene (POPOP) and toluene were obtained from Fisher Chemical Co.

\section{RESULTS}

\section{Nucleotide cyclase activities during development}

When $M$. xanthus $\mathbf{M} 300$ was induced to fruit by inoculation onto FM (fruiting medium, McCurdy et al., 1978), maximum aggregation occurred at approximately $40 \mathrm{~h}$. Fruiting bodies were clearly delimited at about $60 \mathrm{~h}$ and myxospore differentiation was completed between 75 and $85 \mathrm{~h}$. Both adenylate and guanylate cyclases were detectable at levels of activity which varied with the time of development.

The level of adenylate cyclase activity in toluenized vegetative cells was $2-4$ pmol $(\mathrm{mg}$ protein) ${ }^{-1} \min ^{-1}$, but during development it exhibited much higher peaks between 10 and $20 \mathrm{~h}$ and between 40 and $50 \mathrm{~h}$ (Fig. 1). There was also a third, smaller but reproducible peak at about $75 \mathrm{~h}$.

Guanylate cyclase activity in toluenized cells was initially 3-4 pmol (mg protein)-1 $\mathrm{min}^{-1}$ but then rose sharply to a peak between 8 and $20 \mathrm{~h}$, decreased until $40 \mathrm{~h}$ and then rose again to a less dramatic maximum at about $75 \mathrm{~h}$ (Fig. 1).

\section{Guanylate cyclase}

Guanylate cyclase activity was detectable in both the $100000 \mathrm{~g}$ supernatant and pellet (Table 1). Both activities exhibited concave substrate-velocity curves. However, the insolubility of the substrate prevented our obtaining data from higher concentrations which, assuming the usual

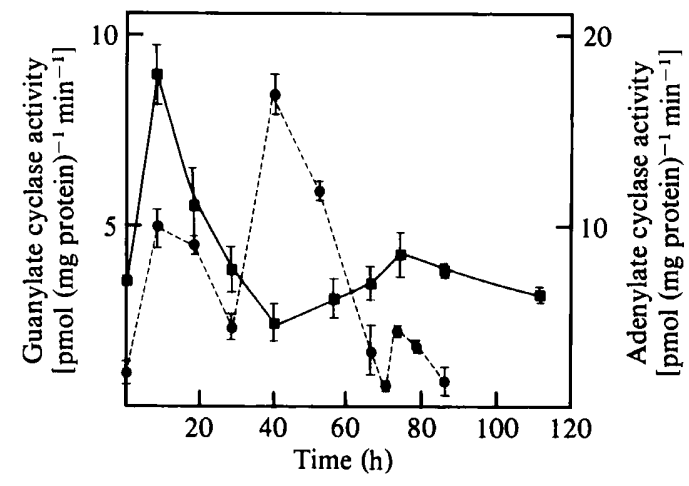

Fig. 1. Activities of cellular adenylate cyclase ( () ) and guanylate cyclase ( $\square$ ) in toluenized Myxococcus xanthus during development plotted as the mean results of five or six separate experiments, with bars showing highest and lowest values detected. 


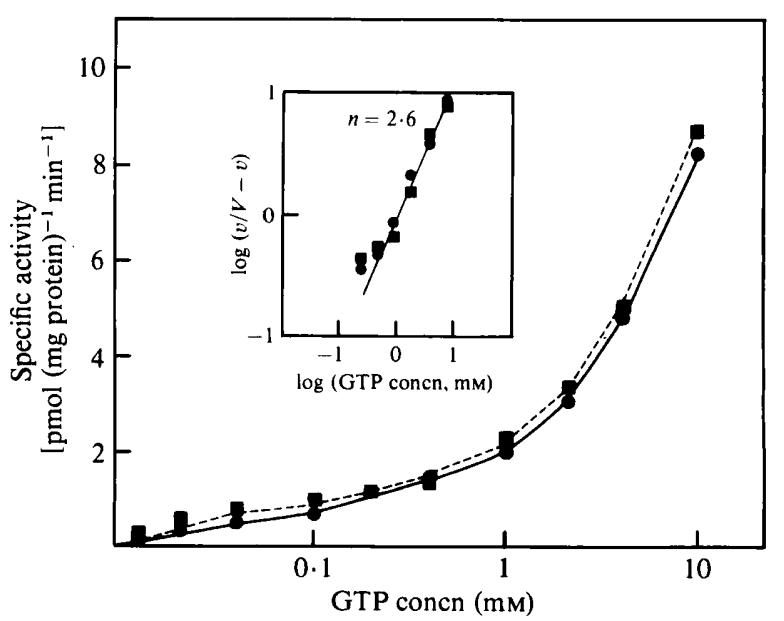

Fig. 2. Substrate-velocity plot of guanylate cyclase activity. The enzyme was assayed in $100000 \mathrm{~g}$ soluble $(\square)$ and particulate $(O)$ fractions of $M$. xanthus. Inset: Hill plot of guanylate cyclase activity obtained using $100000 \mathrm{~g}$ soluble $(\square)$ and particulate $(O)$ fractions at various concentrations of GTP from $10^{-2} \mathrm{M}$ to $10^{-6} \mathrm{M}$.

Table 1. Cyclase activities in the $100000 \mathrm{~g}$ supernatant and pellet fractions

$\begin{array}{lc} & \begin{array}{c}\text { Specific ac } \\ \text { [pmol (mg protein) }\end{array} \\ \text { Adenylate cyclase } & 1.81 \\ \text { Supernatant fraction } & 12 \cdot 1 \\ \text { Pellet fraction } & \\ \text { Guanylate cyclase } & 3.3 \\ \text { Supernatant fraction } & 4.3 \\ \text { Pellet fraction } & \end{array}$

Table 2. Effect of pyruvate, GTP, NaF and cAMP on guanylate cyclase activity

$\begin{array}{lcc}\text { Addition } & \begin{array}{c}\text { Concn } \\ (\mathrm{mM})\end{array} & \begin{array}{c}\text { Guanylate cyclase } \\ \text { activity } \\ (\%)\end{array} \\ \text { Control } & - & 100 \\ \text { Pyruvate } & 4 \cdot 5 & 223 \\ \text { cAMP } & 5.0 & 200 \\ \text { NaF } & 5 \cdot 0 & 99 \\ \text { ATP } & 1.0 & 100\end{array}$

saturation kinetics, would have yielded a sigmoidal curve. Both the supernatant and pellet enzymes had a $K_{\mathrm{m}}$ of $1 \mathrm{~mm}$ and a Hill coefficient of $2 \cdot 6$ (Fig. 2). Accordingly, it appeared that the same enzyme was detected in both fractions and that activity was consistent with positive cooperativity. Guanylate cyclase was dependent on divalent cations: $\mathrm{Mn}^{2+}$ was more effective than $\mathrm{Mg}^{2+}$ or $\mathrm{Ca}^{2+}$, producing optimal activity at $0.15 \mathrm{mM}$, whereas the concentration of $\mathrm{Mg}^{2+}$ for optimal activity was $1.5 \mathrm{~mm}$. The enzyme had a sharp $\mathrm{pH}$ optimum at $\mathrm{pH} 7 \cdot 0$. It was stimulated by cAMP and pyruvate, but neither ATP (Macchia et al., 1981) nor $\mathrm{F}^{-}$(Sun et al., 1974; Macchia et al., 1975) had any effect (Table 2). 


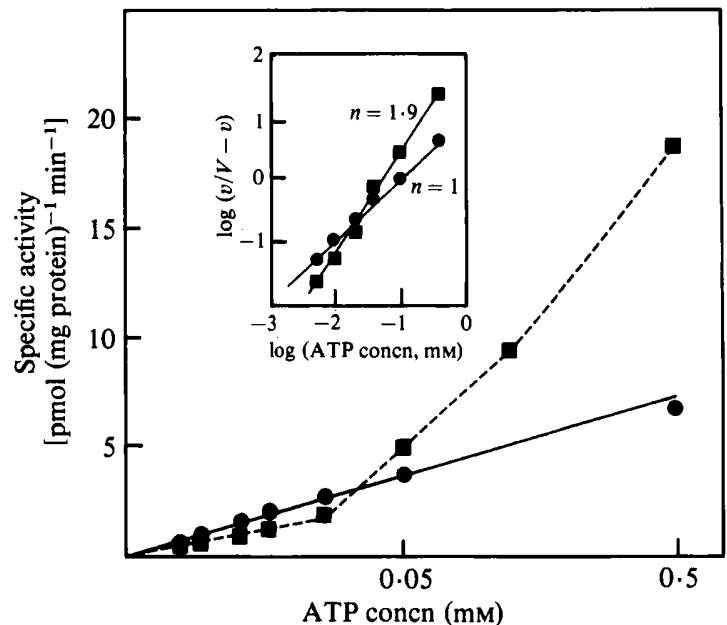

Fig. 3. Substrate-velocity plot of adenylate cyclase activity. The enzyme was assayed in the $100000 \mathrm{~g}$ soluble $(\square)$ and particulate $(\bullet)$ fractions from the vegetative cells of $M$. xanthus. Inset: Hill plot of adenylate cyclase activity obtained using $100000 \mathrm{~g}$ soluble $(\boldsymbol{\square})$ and particulate $(\bullet)$ fractions.

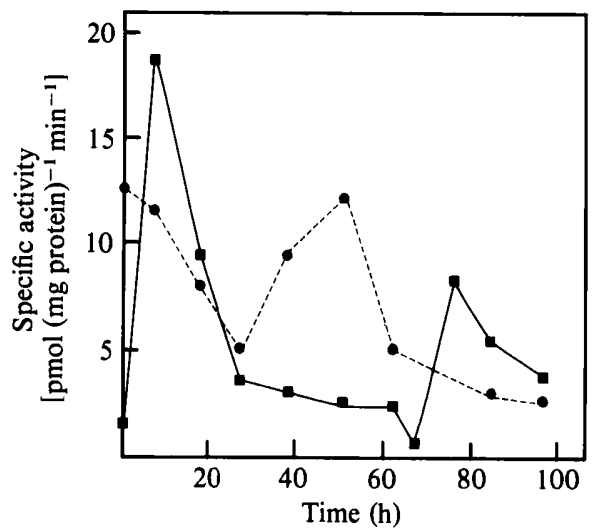

Fig. 4. Adenylate cyclase activity in $100000 \mathrm{~g}$ soluble fraction $(\mathbb{Q})$ and in $100000 \mathrm{~g}$ particulate fraction (O) of Myxococcus xanthus during development. Points represent the mean of two separate determinations.

Table 3. Effect of pyruvate, ATP and NaF on soluble and particulate adenylate cyclase activity

$\begin{array}{llcc}\text { Addition } & \begin{array}{c}\text { Concn } \\ (\mathrm{mM})\end{array} & \overbrace{\text { Supernatant }}^{\begin{array}{c}\text { Adenylate cyclase } \\ \text { activity }(\%)\end{array}} & \text { Pellet } \\ \text { Control } & & 100 & 100 \\ \mathrm{Mn}^{2+} & 1.5 & 736 & 163 \\ \mathrm{Mg}^{2+} & 1.5 & 271 & 105 \\ \text { Pyruvate } & 4.5 & 270 & 103 \\ \text { NaF } & 5.0 & 562 & 98 \\ \text { GTP } & 0.05 & 1200 & 101\end{array}$

\section{Adenylate cyclase}

Adenylate cyclase activity was located in both the $100000 \mathrm{~g}$ supernatant (soluble enzyme) and pellet (particulate enzyme) fractions (Table 1). The $K_{\mathrm{m}}$ for the latter was $72 \mu \mathrm{M}$ and the Hill coefficient was 1 . The supernatant enzyme had an apparent $K_{\mathrm{m}}$ of $220 \mu \mathrm{M}$ and a Hill coefficient of 1.9 , which may indicate positive cooperativity towards the substrate (Fig. 3 ). 
The supernatant enzyme exhibited a sharp $\mathrm{pH}$ optimum at $\mathrm{pH} 8.5$, whereas the pellet enzyme had a broader range of optimal activity between $\mathrm{pH} 7 \cdot 5$ and 9.0. Both enzymes required $\mathrm{Mn}^{2+}$ or $\mathrm{Mg}^{2+}$, with $\mathrm{Mn}^{2+}$ being more effective (Table 3). $\mathrm{Ca}^{2+}$ had no effect on either the soluble or the particulate enzyme.

Soluble enzyme activity was stimulated by pyruvate, NaF and GTP, while the particulate enzyme was not (Table 3).

To determine if the activity peaks seen during development reflected one or both enzymes, changes in soluble and particulate enzyme activities were examined separately during development. Soluble activity exhibited two peaks, one at around $8 \mathrm{~h}$ and another at approximately $75 \mathrm{~h}$ (Fig. 4). Pellet enzyme activity was initially high in vegetative cells, declined and then rose to a peak at around $40 \mathrm{~h}$ (Fig. 4). Hence, while the specific activities determined using toluenized cells were not the resultant from combined specific activities of pellet and supernatant enzymes (the two enzymes perhaps being differentially extracted), the results do seem consistent with the assumption that the first and third peaks observed were attributable to supernatant enzyme, while the second peak was attributable to the pellet enzyme.

\section{DISCUSSION}

The guanylate cyclase of $M$. xanthus resembled other prokaryotic enzymes in its response to $\mathrm{F}^{-}, \mathrm{Mn}^{2+}$ and ATP, as well as its $K_{\mathrm{m}}$ (Clark \& Bernlohr, 1972; Macchia et al., 1975; Sun et al., 1974). On the other hand, it resembled the eukaryotic enzymes in its cooperative response to substrate (Garbers et al., 1975; Chrisman et al., 1975; Craven \& DeRubertis, 1975).

The observation of two forms of adenylate cyclase differing in their solubility and responses to pyruvate accords with findings in other prokaryotes (Ide, 1971; Khandelwal \& Hamilton, 1971). However, the soluble form resembled the eukaryotic enzyme in being stimulated by GTP and $\mathrm{NaF}$ (Bhat et al., 1980).

Adenylate cyclase activity exhibited peaks at critical periods in development. The first peak of activity occurring around $8 \mathrm{~h}$ could be responsible for the peak of cAMP concentration previously reported to occur between 0 and $20 \mathrm{~h}$ (Ho \& McCurdy 1980). The $40 \mathrm{~h}$ peak, while coincident with aggregation, did not correlate with any observed increase in cAMP concentration (Yajko \& Zusman, 1978; Ho \& McCurdy, 1980). This may have been due to high PD activity observed at that stage (Ho \& McCurdy, 1980). The third peak occurred around $75 \mathrm{~h}$ when microcyst formation within fruiting bodies was initiated. Previous studies (McCurdy et al., 1978; Yajko \& Zusman, 1978) had demonstrated a sharp peak in cAMP content during early development of glycerol induced myxospores.

McCurdy et al. (1978) suggested that cAMP is involved in derepressing differentiation specific operons at two critical times: first, shortly after induction of fruiting body formation; second, on initiation of myxospore induction. Consistent with these expectations, it was the soluble, apparently allosteric form of adenylate cyclase which exhibits maxima at these critical times.

Guanylate cyclase activity exhibited a peak of activity between 0 and $20 \mathrm{~h}$, a time which slightly precedes intracellular and subsequent extracellular accumulation of cGMP associated with aggregation (Ho \& McCurdy, 1980). Similarly, the second peak in the activity corresponds to the second rise in cGMP concentration late in development, as reported earlier (Ho \& McCurdy, 1980).

If one takes into account the PD activities, it appears that cyclic nucleotide accumulation is largely a reflection of cyclase activities which exhibit a pattern consistent with a role in differentiation in $M$. xanthus.

\section{REFERENCES}

Bhat, M. K., Lyener, R., Abramowitz, J., BordeLON-RISER, M. E. \& BiRNBAUER, L. (1980). Naturally soluble component(s) that confer(s) guanine nucleotide and fluoride sensitivity to adenylate cyclase.
Proceedings of the National Academy of Sciences of the United States of America 77, 3836-3840.

Brooker, G., Harper, J. F., Terasaki, W. L. \& MOYLAN, R. D. (1979). Radioimmunoassay of cyclic 
AMP and cyclic GMP. Advances in Cyclic Nucleotide Research 10, 1-33.

Chrisman, T. D., Garbers, D. L., Parks, M. A. \& HaRdman, J. G. (1975). Characterization of particulate and soluble guanylate cyclases from rat lung. Journal of Biological Chemistry 250, 374-381.

Clark, V. L. \& Bernlohr, T. W. (1972). Guanyl cyclase of Bacillus licheniformis. Biochemical and Biophysical Research Communications 46, 1570-1575.

Craven, P. A. \& DeRubertis, D. R. (1975). Properties and subcellular distribution of guanylate cyclase activity in rat renal medulla: correlation with tissue content of guanosine $3^{\prime}, 5^{\prime}$-monophosphate. Biochemistry 15, 5131-5137.

Garbers, D. L. \& Murad, F. (1979). Guanylate cyclase assay methods. Advances in Cyclic Nucleotide Research 10, 57-67.

Garbers, D. L., Dyer, E. L. \& Hardman, J. G. (1975). Effect of cations on guanylate cyclase of sea urchin sperm. Journal of Biological Chemistry 250, 382-387.

Harwood, T. \& Peterkofsky, A. (1975). Glucosesensitive adenylate cyclase in toluene-treated cells of Escherichia coli B. Journal of Biological Chemistry 250, 4656-4662.

Ho, J. \& MCCuRDY, H. D. (1979). Demonstration of positive chemotaxis to cyclic GMP and 5 -AMP in Myxococcus xanthus by means of a simple apparatus for generating practically stable concentration gradients. Canadian Journal of Microbiology 25, 12141218.

Ho, J. \& MCCuRdy, H. D. (1980). Sequential changes in the cyclic nucleotide levels and cyclic nucleotide phosphodiesterase activities during development of Myxococcus xanthus. Current Microbiology 3, 197202.

IDE, M. (1971). Adenylate cyclases of bacteria. Archives of Biochemistry and Biophysics 144, 262-268.

Khandelwal, R. L. \& Hamilton, J. R. (1971). Purification and properties of adenylate cyclase of
Streptococcus salivarius. Journal of Biological Chemistry 246, 3297-3304.

Macchia, V., Vanone, S., Weissbach, M., Miller, D. C. \& PAStan, I. (1975). Guanylate cyclase in Escherichia coli. Journal of Biological Chemistry 250, 62146217.

Macchia, V., Caputo, G., Mandata, E., Rocino, A., AdHyA, S. \& Pastan, I. (1981). Guanylate cyclase activity in Escherichia coli mutants defective in adenylate cyclase. Journal of Bacteriology 147, 931934.

McCurdy, H. D., Ho, J. \& Dobson, W. J. (1978). Cyclic nucleotide phosphodiesterase and development in Myxococcus xanthus. Canadian Journal of Microbiology 24, 1475-1481.

Parish, J. H., Wedgewood, R. \& Herries, D. G. (1976). Morphogenesis in Myxococcus xanthus and Myxococcus virescens (Myxobacterales). Archives of Microbiology 107, 343-351.

Steiner, A. L., Parker, C. \& Kipnis, D. M. (1972). Radioimmune assay for cyclic nucleotides. I. Preparation of antibodies and iodinated cyclic nucleotides. Journal of Biological Chemistry 247, 11061113.

Sun, I. L., Shapiro, L. \& Rosen, O. M. (1974). Purifcation and characterization of guanyl cyclase from Caulobacter crescentus. Biochemical and Biophysical Research Communications 61, 193-203.

Terasaki, W. L., BroOKer, G., DE VILlis, J., INGLISH, D., Hsu, C.-Y. \& Moylan, R. D. (1978). The involvement of cyclic AMP in protein synthesis in catecholamine refractoriness. Advances in Cyclic Nucleotide Research 9, 33-52.

YAJKo, D. L. \& ZuSMAN, D. (1978). Changes in cAMP levels during development in Myxococcus xanthus. Journal of Bacteriology 133, 1540-1542.

ZuSMAN, D. R. (1978). A rapid batch assay for cyclic AMP phosphodiesterase. Analytical Biochemistry 84, 551-558. 